\title{
How Mobile Devices Affect Students According To Teachers' Beliefs
}

\author{
Gonca Kızılkaya Cumaoğlu, Ph.D., Yeditepe University, Turkey
}

\begin{abstract}
The purpose of this study is to examine teachers' beliefs concerning the effects on students using mobile devices, and to determine whether these beliefs vary according to the demographic characteristics and Internet usage purposes. For this purpose, a demographic information questionnaire and the scale developed by Diker Coskun \& Kizilkaya Cumaoglu (2013) were revised with validity and reliability studies and utilized on teachers $(N=200)$. In total, the scale has three dimensions (with a total of 15 items). These are social effects (9 items), psychological effects (3 items), and learning-related effects (3 items). According to the results of the study, teachers believe that students are affected by mobile devices on all three dimensions of the scale (social, psychological, and learning dimensions). The most striking finding of the study is related to the learning dimension of the beliefs concerning mobile devices scale. In every Internet usage purpose examined within the study, it was determined that the teachers' beliefs concerning the "learning" dimension are always more positive than those that do not use the Internet for any given purpose.
\end{abstract}

Keywords: Mobile Device; Teacher Beliefs; Mobile Learning; Internet Usage

\section{INTRODUCTION}

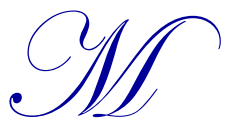

obile devices are among the most commonly used and observable technologies of the modern day. Examining the age group of mobile device users shows that almost the entire generation that is referred to as digital-native starts with children 3 years of age using mobile devices. The positive and negative effects of these devices on humans and particularly on children are within the field of interest of social sciences, as are those of all new technologies. On the other hand, the field of instructional technology focuses on the utilization of all emerging technologies for teaching purposes. Considering the matter from this perspective, it is possible to view mobile devices both as a form of instructional technology and as tools that affect student behaviors in social and psychological terms. Accordingly, the beliefs of teachers, who naturally have the highest opportunity to observe children at school, on mobile devices that are considered likely to affect children in social, psychological, and learning-related terms, gain importance. These beliefs do not only indicate how students are being affected by mobile devices, but also will form a reference to teachers' capacity to utilize this technology both within and outside of the classroom for teaching purposes. With this consideration, the present study focuses on teachers' beliefs concerning the effects of mobile devices on students and the relation of these beliefs with Internet usage frequency and purposes.

\section{BACKGROUND}

The two most important components of this study are teacher beliefs and the use of mobile devices by students in school and learning environments within the context of information and communications technology (ICT). Due to this reason, these two components were examined while forming the theoretical structure of the study.

\section{Teachers Beliefs}

Beliefs are implicit, unobservable, and complex in relation to what one knows and what one actually believes; both the labels and the definitions of teacher beliefs used in the literature are diverse and difficult to define. 
However, specific ideas from a substantive body of knowledge about teacher beliefs are evident to help us to understand and deal effectively with the complexity of beliefs (Prestridge, 2012). It is known that teacher beliefs affect teachers' identities and teaching implementations (Clark \& Peterson, 1986; Fang, 1996; Kagan, 1992; Kane, Sandretto, \& Heath, 2002; Pajares, 1992; Prawat, 1992; Zeichner \& Tabachnick, 1985, as cited in Hermans et al, 2008). For this purpose, the literature includes many scale-development studies intended to determine teacher beliefs. A portion of them are encountering the beliefs on the utilization and acceptance of instructional technologies (Lumpe \& Champers, 2001; Brush, Glazewski \& Hew, 2008). Measuring and attempting to understand teacher beliefs will not only be useful in regulating teaching implementations, but will also help in forming teachers' education. Indeed, Fullan's $(1982,1991,2000)$ theory of school change also emphasizes that the alteration of mindsets, such as pedagogical assumptions, values, and beliefs, is a key factor to any educational change effort (as cited in Papanastasiou \& Angeli, 2008).

One of the important aspects of educational change that takes place in the school is ICT integration into classroom environment. It was determined that belief is one of the seven factors that best explain teachers' predictive power concerning ICT integration processes (Kaya \& Usluel, 2011). As a matter of fact, teachers' beliefs being one of the most important factors related to the use of technology in the classroom is a point supported also by several studies (Blackwell et al., 2013; Chen, 2008; Drent \& Meelissen, 2008). Researchers have also reported that failed ICT integration attempts did not take teachers' beliefs, attitudes, and skills into consideration (Cuban, 2000; Becker \& Ravitz, 1999; Bosch \& Cardinale, 1993; Brush, 1998; Darling-Hammond, 1990; Ely, 1995; Hunt \& Bohlin, 1995, as cited in Papanastasiou \& Angeli, 2008). In this sense, teachers' beliefs concerning the effects of mobile device usage on social, psychological, and learning-related effects is important both in terms of ICT integration in classroom and in terms of the policies to be implemented in training teachers.

\section{Mobile Devices for Learning}

Druin (2009) states that the children of the present generation, whom we refer to as I-children, can easily adapt to and manipulate all type of new technology and screen-based design. However, the educational needs, skills and interests of these "I-children", who have a high capacity to adapt themselves to new technologies, differ. Therefore, while it is essential to ensure that these needs are met and educational environments are regulated accordingly, the social and psychological effects of the new technologies must also be taken into consideration. Among these technologies, mobile devices are those that are most convenient to use in the classroom and in personal life. As a matter of fact, mobile devices seem to be capable of solving the dilemma between the classroom and the computer laboratory by enabling students to participate in both physical and virtual learning activities (Liu et al. 2003). With the same perspective, Rossing, Miller, Cecil \& Stamper (2012) define mobile learning as "the efficient and effective use of wireless and digital devices and technologies to enhance learners' individual outcomes during participation in learning activities."

There have been many studies on the probable effects of mobile devices in school and on learning, and their roles and effects within the teaching-learning process (Chen \& Katz, 2009; Yang, 2012; Hoadley, 2009; Ching, Shuler, Lewis \& Levine, 2009; Uzunboylu \& Ozdamli, 2011; Cheon, Lee, Croocs \& Song, 2012; Sung \& Mayer, 2012). Several studies have also reported that mobile learning positively contributes to student success (De-Marcos et al. 2010; Hwang, Wu \& Ke, 2011; Şad \& Akdağ, 2010). It is considered that also the use of mobile devices outside the classroom is helpful for learning (Jacobijn Sandberg, Marinus Maris \& Kaspar de Geus, 2011). Through mobile devices, students create their own learning network and carry out messaging and social network activities with their friends and teachers (Field, 2005). In addition, it was observed that teachers positively utilize mobile devices concerning the writing skills of students with special educational needs (Swan, Hooft \& Kratcoski, 2005). Accordingly, it is possible to assert that students that have different educational needs may benefit from mobile devices through various means.

The use of mobile devices, which are considered to contribute to learning and their integration in the classroom, in a sense depends on teachers' beliefs on this matter. Therefore, knowing teachers' beliefs and examining the variables that affect these beliefs would have an impact on the use of these technologies in the classroom for learning purposes. In addition, the fact that these opinions are the outputs of some observations may also be used as a reference to determine the extent with which students are actually affected by these devices. 
To examine the teacher' beliefs towards the use of mobile devices by students in Turkey, this study surveyed 200 elementary school teachers in using a revised scale formerly developed by Diker Coşkun \& K1zılkaya Cumaoğlu (2013).

\section{RESEARCH QUESTIONS:}

1) According to the teachers' beliefs, how students using mobile devices are affected in social, psychological, and learning-related terms?

2) Do teachers' beliefs concerning students' use of mobile devices vary according to the teachers' age, gender, or the type of organization they work in?

3) Do teachers' beliefs concerning students using of mobile devices vary on the basis of the teachers' Internet usage purpose?

\section{METHOD}

A descriptive research method was employed in the present study. For this purpose, data were collected through the survey model and by means of the "Teachers' beliefs concerning mobile devices scale".

\section{Study Group}

The study group consisted of 200 teachers serving primary schools in Turkey's largest metropolis, Istanbul. Teachers of different branches (IT, mathematics, classroom teaching, social sciences, etc...) were selected from a total of six different schools with three private and three public schools. In the selection of the schools, being representative of the country-average in terms of socio-economics and student success, and having "visible" mobile device usage were determined as the criteria.

Table 1. Demographic information of the study group

\begin{tabular}{lll}
\hline Gender & Woman & $64 \%(\mathrm{~N}=128)$ \\
\cline { 2 - 3 } & Men & $36 \%(\mathrm{~N}=72)$ \\
\hline Teaching Experience & & $36 \%(\mathrm{~N}=72)$ \\
\hline $1-5$ years & & $28 \%(\mathrm{~N}=56)$ \\
$6-10$ years & $25.5 \%(\mathrm{~N}=51)$ \\
$11-20$ years & $9 \%(\mathrm{~N}=18)$ \\
$21-30$ years & $1.5(\mathrm{~N}=3)$ \\
$31-40$ years & \\
\hline School Type & $45 \%(\mathrm{~N}=90)$ \\
\hline Government & $55 \%(\mathrm{~N}=110)$ \\
Private & $\mathrm{N}=200$ \\
\hline Total & \\
\hline
\end{tabular}

\section{Instruments}

Within the scope of the study the scale that was developed by Diker, Kizilkaya \& Cumaoglu (2013) to measure teachers' beliefs concerning the effects of using mobile devices on students, was revised and utilized. The validity and reliability study of the scale is presented below. Furthermore, a questionnaire was used in order to determine the participating teachers' demographic data such as their gender, age, and type of school they attend to.

\section{Scale of Teachers' Beliefs Concerning Mobile Devices}

Scientific studies have proven that new technologies, and particularly mobile technologies with such personal and frequent use, affect human behaviors in social and psychological terms (Bianchi \& Philips, 2005; Takaho, Takahashi \& Kitamura, 2009; Kamibeppu \& Sugiura, 2005; Beranuy, Oberst, Carbonell \& Chamarro, 2009; Thomée, Härenstam \& Hagberg, 2011; Yen, Tang, Yen, Lin, Huang, Liu \& Ko, 2009). Accordingly, when it is planned to develop a scale in order to examine teachers' beliefs concerning mobile devices, social and psychological aspects should also be taken into consideration. When students are in question, then these effects 
should also be examined in terms of learning. As a matter of fact, the learning-oriented use of mobile devices is rapidly becoming common in mobile learning environments. Accordingly, these three factors were taken into consideration during the revision of the scale and new items were added to the scale in line with the opinions received from experts of the field of Psychological Counseling and Guidance.

In total, the scale has three dimensions (with a total of 15 items). These include: social effects (9 items), psychological effects ( 3 items), and learning-related effects ( 3 items).

In order to express the agreement level (agreeing or disagreeing with a particular opinion) concerning the 15 items included in the scale, a 5-point Likert-type measuring system was used. This rating system was arranged with the choices of "Strongly Disagree (5), Disagree (4), Undecided (3), Agree (2), and Strongly Agree (1)". In the evaluation of the scores attained from the scale, reverse scoring was made from positive answers to negative ones. This is because the items of the scale are of a nature that indicates negative effects. In other words, higher total scores attained from the scale indicate more positive beliefs concerning the use of mobile devices. The items of the scale are designed to explore the negative effects of mobile device usage, except for one item. Teachers that stated their agreement with such items were evaluated to have negative beliefs on the matter. Thus, it was ensured that when the scoring system of the scale is inverted, higher scores indicate positive beliefs.

\section{Validity Study}

For face and scope validity, the 28 -item scale was submitted to the review of four experts, including one from the field of Psychological Counseling and Guidance, one from the field of assessment and evaluation, and one from the field of Computer Teaching Technologies Education. The items were rearranged on the basis of the feedback received from the experts concerning language, expression and scope validity. Validity and reliability studies of the scale development process were carried out with 28 items.

In the determination of the items to be included in the scale during the performance of the Exploratory Factor Analysis, it was ensured that the eigenvalues of factors are 1, item factor loads are at least 0.30 and, that there is at least a 0.10 difference between factors for items included in the two factors. The fitness of the item-factor structure obtained from the Exploratory Factor Analysis to the model was tested through the performance of a Confirmatory Factor Analysis.

Exploratory Factor Analysis (EFA) (principal components analysis): In the Exploratory Factor Analysis (EFA), conducted to examine the structural validity of the scale, at first the correlation matrix between all items was examined to see whether there are significant correlations, and it was observed that there are significant relations that enable the performance of factor analysis. Afterwards, Kaiser-Meyer-Olkin (KMO) and Bartlett Sphericity tests were conducted. A KMO rate higher than 0.60 and the $p$ value in the Bartlett test being lower than 0.01 indicate that the dataset is fit for principal components analysis (Buyukozturk, 2002). In our study, the KMO value 0.871 and the Bartlett test was determined to be significant $(\mathrm{p}<0.01)$.

Twelve items in the scale were excluded from the scope of the scale due to having low factor loads $(<0.30)$ and being unfit for the dimension to be measured. Another item was also excluded from the scale in line with the experts' opinions, since it exhibited high loads under two different factors and being unfit for the factor that is intended to measure a certain aspect. In cases where the difference between cross items that significantly contribute to the scope validity of sub-dimensions was less than 0.20 , the items fitting the sub-dimension were preferred (Plotinkoff, 1994). The scale was once again subjected to factor analysis in the form of 15 items, and its components matrix rotated through Varimax method are presented in Table 2. The final form of the scale includes 15 items.

According to the results of the analysis, Table 2 presents nine items related to the "social effects" factor that measures the social aspect of the scale, and the factor load values of these items varied between the 0.792 and 0.550 . There were three items in related to the "psychological effects" factor, the load values of which varied between 0.747 and 0.648 . The third factor, "learning-related effects" also consisted of three items and their factor load values were between 0.754 and 0.685 . As a result, the total variance explained by these three factors was 54.54 . 
Table 2. Factor Analysis Results of the Scale - Rotated Components Matrix

\begin{tabular}{|c|c|c|c|c|}
\hline & \multirow{2}{*}{ Item No } & \multicolumn{3}{|c|}{ Factor Loads } \\
\hline & & Social & Psychological & Learning \\
\hline \multirow{9}{*}{$\begin{array}{l}\bar{\pi} \\
\overline{0} \\
\text { D }\end{array}$} & 6 I believe that mobile devices isolate students. & 0.792 & 0.051 & 0.121 \\
\hline & $\begin{array}{l}5 \text { I believe that students using mobile devices have difficulties } \\
\text { in complying with the rules of the school. }\end{array}$ & 0.745 & 0.057 & 0.159 \\
\hline & $\begin{array}{l}1 \text { I believe that mobile devices (tablets, smart phones, etc.) } \\
\text { prevent students from socializing. }\end{array}$ & 0.691 & 0.102 & 0.146 \\
\hline & $\begin{array}{l}10 \text { I believe that mobile devices cause problems in children's } \\
\text { communication within their families. }\end{array}$ & 0.684 & 0.349 & 0.054 \\
\hline & $\begin{array}{l}4 \text { Students using mobile devices experience difficulty in } \\
\text { communicating with their peers. }\end{array}$ & 0.662 & 0.066 & 0.144 \\
\hline & $\begin{array}{l}20 \text { Students using mobile devices experience difficulty in } \\
\text { communicating with their teachers. }\end{array}$ & 0.610 & 0.328 & 0.141 \\
\hline & $\begin{array}{l}17 \text { I think the interest students have in mobile devices prevents } \\
\text { them from participating in social activities. }\end{array}$ & 0.570 & 0.238 & -0.266 \\
\hline & $\begin{array}{l}12 \text { Students feel compelled to use mobile devices to gain } \\
\text { "social acceptance.". }\end{array}$ & 0.556 & 0.334 & 0.006 \\
\hline & $\begin{array}{l}27 \text { I believe that students using mobile devices experience } \\
\text { problems with social skills. }\end{array}$ & 0.550 & 0.345 & -0.126 \\
\hline \multirow{3}{*}{ 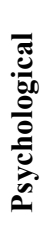 } & $\begin{array}{l}7 \text { I consider students interest towards mobile devices is at a } \\
\text { level of addiction. }\end{array}$ & -0.016 & 0.747 & 0.088 \\
\hline & $\begin{array}{l}15 \text { I observe that students that became used to use mobile } \\
\text { devices at younger ages are more impatient than their peers. }\end{array}$ & 0.331 & 0.718 & -0.021 \\
\hline & $\begin{array}{l}14 \text { I believe that the intensive use of mobile devices cause a } \\
\text { lack of attention in students. }\end{array}$ & 0.443 & 0.648 & 0.013 \\
\hline \multirow{3}{*}{ } & $\begin{array}{l}24 \text { I believe that students' mobile device usage has a positive } \\
\text { effect on their success in multiple-choice exams. }\end{array}$ & 0.173 & 0.111 & 0.754 \\
\hline & 21 Mobile device usage lowers students' academic success. & 0.092 & 0.091 & -0.687 \\
\hline & 28 Mobile device usage improves students' thinking skills. & 0.210 & 0.081 & 0.685 \\
\hline \multicolumn{2}{|c|}{ Eigenvalue $($ Total $=8.03)$} & 5.27 & 1.66 & 1.10 \\
\hline \multicolumn{2}{|c|}{ Total explained variance $(\%)=54.54$} & 28.43 & 13.72 & 11.39 \\
\hline
\end{tabular}

\section{Confirmatory Factor Analysis}

In order to test the model obtained from the exploratory factor analysis (EFA), a Confirmatory Factor Analysis was carried out. This analysis was conducted on the sample on which the EFA was previously conducted with the use of the 15 -item scale $(\mathrm{N}=200)$. The findings obtained as a consequence of the confirmatory factor analysis conducted on the established model are presented in Table 3 . The $\chi^{2} / d f$ value was $(180.93 / 87=2.09)$ and it was determined that the results of the CFA exhibit an acceptable fit. [SRMR $=0.061, \mathrm{AGFI}=0.85, \mathrm{RMSEA}=0.073$, $\mathrm{IFI}=0.91]$. RMSEA values, on the other hand, vary between 0 and 1 . The closer these values are to 0 , the better fit they exhibit. The rate $\chi 2 / \mathrm{df}$ is an indication of a good fit and if it is lower than 2 , it indicates a perfect fit (Jöreskog \& Sörbom, 1993; Kline, 2005). For cases where the sample size matters, it is more appropriate to use IFI instead of indexes such as CFI (Bolen, 1990). Due to this reason, while examining fitness values, the IFI value was reported. The range of indices suitable for confirmatory factor analysis is presented in Table 3. 
Table 3. Recommendations for Model Evaluation and scale values

\begin{tabular}{llll}
\hline \multicolumn{1}{c}{ Fit Measure } & \multicolumn{1}{c}{ Good Fit } & \multicolumn{1}{c}{ Acceptable Fit } & Scale Values \\
\hline$\chi^{2} / d f$ & $0 \leq \chi^{2} / d f \leq 2$ & $2<\chi^{2} / d f \leq 3$ & 2.08 \\
RMSEA & $0 \leq R M S E A \leq 0.05$ & $0.05<R M S E A \leq 0.08$ & 0.073 \\
SRMR & $0 \leq S R M R \leq 0.05$ & $0.05<S R M R \leq 0.10$ & 0.061 \\
IFI & $0.97 \leq I F I \leq 1.00$ & $0.90 \leq I F I<0.97^{\circ}$ & 0.91 \\
AGFI & $0.90 \leq A G F I \leq 1.00$ & $0.85 \leq$ AGFI $<0.90$ & 0.85 \\
\hline
\end{tabular}

(Schermelleh-Engel, Moosbrugger, \& Müller, 2003 p.52; Bolen, 1990)

\section{Reliability Study}

In order to determine the reliability of the study, Cronbach's alpha $(\alpha)$ reliability coefficient was calculated. The Cronbach alpha $(\alpha)$ reliability coefficient of the scale applied to 200 teachers was determined to be 0.89 . This value indicates that the scale is highly reliable (Nunnally, 1978; As cited in Gadermann, Guhn \& Zumbo, 2012). The reliability coefficients pertaining to the sub-dimensions are presented in Table 4. The fact that the Cronbach's alpha values of the sub-dimensions are lower than the total Cronbach alpha value of the scale may be explained with a few items in the sub-dimensions.

Table 4. The results regarding reliability of the scale

\begin{tabular}{llccc}
\hline \multicolumn{1}{c}{ Dimensions } & Social & Psychological & Learning & Cronbach's $\boldsymbol{\alpha}$ \\
\hline Social & 1 & & & 0.86 \\
Psychological & $0.781^{*}$ & 1 & 1 & 0.66 \\
Learning & $0.553^{*}$ & $0.398^{*}$ & $0.694^{*}$ & 0.52 \\
Scale total & $0.972^{*}$ & $0.839^{*}$ & 0.85 \\
\hline
\end{tabular}

$* \mathrm{p}<0.05$

An examination of Table 4 shows that the correlation between the factors varied within the range of 0.781 and 0.398 , and that there was a statistically significant relationship between them $(\mathrm{p}<0.05)$. These findings establish that there is consistency between the factors of the scale and that their correlation is high.

\section{FINDINGS}

RQ1: According to teachers' beliefs, how are students use of mobile devices affected in social, psychological, and learning-related terms?

The 15-item scale consisting of three sub-dimensions (social, psychological and learning) was utilized to measure teachers' beliefs. The points attained from the social effects dimension were between 5 and 45 . The average score the teachers was 20.6. From this average, it is possible to assert that the teachers believe that mobile devices moderately affect students in social terms. The scores attained from the psychological effect dimension of the scale varied between 3 and 15 points with an average of 6.24. As for the scores attained from the learning dimension, they once again varied between 3 and 15 points, with an average of 8.06. Examining the average scores pertaining to psychological effects and learning-related effects, it can be seen that teachers' beliefs concerning the learning-related effects is more positive.

Table 5. Descriptive results of the scale

\begin{tabular}{lcrll}
\hline \multicolumn{1}{c}{ Dimension } & $\mathbf{N}$ & $\overline{\boldsymbol{X}}$ & S. D. & S. E \\
\hline Social (9 items) & 200 & 20.60 & 6.304 & 0.446 \\
Psychological (3 items) & 200 & 6.24 & 2.133 & 0.151 \\
Learning (3 items) & 200 & 8.06 & 2.250 & 0.159 \\
Scale total & 200 & 34.90 & 9.479 & 0.670 \\
\hline
\end{tabular}

RQ2: Do teachers' beliefs concerning students' use of mobile devices vary according to the teachers' age, gender, or the type of organization in which they work? 
Table 6 presents the average scores teachers of different age groups attained from the scale. In order to determine the significant differences between these points, a single-factor (one-way) ANOVA analysis was carried out. Tukey's post-hoc test was conducted to determine which age group mean significantly differed from the others. According to the results of Tukey's test, teachers included in the 46-55 age group expressed less positive beliefs in comparison with those included in the 20-25, 26-35, and 36-45 age groups. While this difference was statistically significant under the social effect sub-dimension, no statistical significance could be found under the subdimensions of learning-related and psychological effects.

Table 6. The results of scale regarding teachers' different age group

\begin{tabular}{lcrrrr}
\hline \multicolumn{1}{c}{ Dimension } & Age Group & $\mathbf{N}$ & $\overline{\boldsymbol{X}}$ & $\mathbf{S .}$ D. & S. E \\
\hline \multirow{5}{*}{ Social } & $20-25$ & 34 & 20.94 & 6.541 & 1.122 \\
& $26-35$ & 95 & 20.78 & 5.316 & 0.545 \\
& $36-45$ & 51 & 21.76 & 6.895 & 0.966 \\
& $46-55$ & 15 & 15.27 & 6.923 & 1.787 \\
Psychological & Over 55 & 5 & 19.00 & 8.307 & 3.715 \\
& $20-25$ & 34 & 6.59 & 2.439 & 0.418 \\
& $26-35$ & 95 & 6.29 & 1.744 & 0.179 \\
Learning & $36-45$ & 51 & 6.29 & 2.484 & 0.348 \\
& $46-55$ & 15 & 5.20 & 2.396 & 0.619 \\
& Over 55 & 5 & 5.60 & 1.673 & 0.748 \\
\hline \multirow{5}{*}{ Scale total } & $20-25$ & 34 & 7.88 & 1.996 & 0.396 \\
& $26-35$ & 95 & 8.06 & 2.361 & 0.205 \\
& $36-45$ & 51 & 8.51 & 2.757 & 0.331 \\
& $46-55$ & 15 & 6.80 & 3.050 & 0.712 \\
& Over 55 & 5 & 8.40 & 10.381 & 1.364 \\
\hline
\end{tabular}

Table 7. The results of ANOVA regarding age differences on beliefs of teachers

\begin{tabular}{|c|c|c|c|c|c|c|}
\hline & Source of Variance & $\begin{array}{c}\text { Sum of } \\
\text { Squares }\end{array}$ & df & $\begin{array}{c}\text { Mean } \\
\text { squares }\end{array}$ & $\mathbf{F}$ & $\mathbf{p}$ \\
\hline \multirow{3}{*}{ Social } & Between subjects & 515.650 & 4 & 128.912 & 3.401 & 0.010 \\
\hline & Within subjects & 7392.350 & 195 & 37.909 & & \\
\hline & Total & 7908.000 & 199 & & & \\
\hline \multirow{3}{*}{ Psychological } & Between subjects & 22.824 & 4 & 5.706 & 1.261 & 0.287 \\
\hline & Within subjects & 882.171 & 195 & 4.524 & & \\
\hline & Total & 904.995 & 199 & & & \\
\hline \multirow{3}{*}{ Learning } & Between subjects & 35.784 & 4 & 8.946 & 1.796 & 0.131 \\
\hline & Within subjects & 971.496 & 195 & 4.982 & & \\
\hline & Total & 1007.280 & 199 & & & \\
\hline \multirow{3}{*}{ Total } & Between subjects & 1048.296 & 4 & 262.074 & 3.036 & 0.019 \\
\hline & Within subjects & 16832.899 & 195 & 86.323 & & \\
\hline & Total & 17881.195 & 199 & & & \\
\hline
\end{tabular}

Table 8. Tukey test results for age groups

\begin{tabular}{|c|c|c|c|c|c|}
\hline \multicolumn{3}{|c|}{ Comparison } & \multirow{2}{*}{$\begin{array}{c}\text { Mean difference } \\
(\mathrm{I}-\mathrm{J}) \\
\end{array}$} & \multirow[b]{2}{*}{ S. E. } & \multirow[b]{2}{*}{ p } \\
\hline & I & $\mathbf{J}$ & & & \\
\hline \multirow{3}{*}{ Social } & \multirow{3}{*}{$46-55$} & $20-25$ & -5.675 & 1.908 & $.027^{*}$ \\
\hline & & $26-35$ & -5.512 & 1.711 & $.013^{*}$ \\
\hline & & $36-45$ & -6.498 & 1.808 & $.004 *$ \\
\hline \multirow{3}{*}{ Total } & \multirow{3}{*}{$46-55$} & $20-25$ & -8.145 & 2.880 & $.041^{*}$ \\
\hline & & $26-35$ & -7.870 & 2.581 & $.022 *$ \\
\hline & & $36-45$ & -9.302 & 2.729 & $.007 *$ \\
\hline
\end{tabular}

$\mathrm{p}>0.05$ 
The collected data were subjected to a t-test in order to determine whether teachers' beliefs related to mobile devices changed according to their gender. The results of the analysis are presented in Table 9. The results indicate that teacher' beliefs concerning students' use of mobile devices do not differentiate on the basis of the teachers' gender.

Table 9.The results of t-test regarding gender differences on beliefs of teachers

\begin{tabular}{|c|c|c|c|c|c|c|c|c|}
\hline & Gender & $\mathbf{N}$ & $\bar{X}$ & S. D. & S. E. & $\mathbf{t}$ & df & $\mathbf{p}$ \\
\hline \multirow{2}{*}{ Social } & Female & 128 & 20.91 & 6.217 & 0.550 & \multirow{2}{*}{0.916} & \multirow{2}{*}{198} & \multirow{2}{*}{0.361} \\
\hline & Male & 72 & 20.06 & 6.463 & 0.762 & & & \\
\hline \multirow{2}{*}{ Psychological } & Female & 128 & 6.32 & 2.238 & 0.198 & \multirow{2}{*}{0.665} & \multirow{2}{*}{198} & \multirow{2}{*}{0.507} \\
\hline & Male & 72 & 6.11 & 1.940 & 0.229 & & & \\
\hline \multirow{2}{*}{ Learning } & Female & 128 & 8.13 & 2.202 & 0.195 & \multirow{2}{*}{0.544} & \multirow{2}{*}{198} & \multirow[b]{2}{*}{0.587} \\
\hline & Male & 72 & 7.94 & 2.343 & 0.276 & & & \\
\hline \multirow{2}{*}{ Total } & Female & 128 & 35.35 & 9.451 & 0.835 & \multirow{2}{*}{0.888} & \multirow{2}{*}{198} & \multirow{2}{*}{0.376} \\
\hline & Male & 72 & 34.11 & 9.544 & 1.125 & & & \\
\hline
\end{tabular}

In order to determine whether the type of organization the teachers work in affects the scores they attained from the scale, the data were subjected to a t-test. According to the results presented in Table 10, the teachers working in public schools and those that work in private schools have no statistically significant differences in terms of their beliefs concerning mobile device use.

Table 10. The t-test results regarding school type differences on beliefs of teachers

\begin{tabular}{|c|c|c|c|c|c|c|c|c|}
\hline & Organization & $\mathbf{N}$ & $\overline{\bar{X}}$ & S. D. & S. E. & $\mathrm{t}$ & df & $\mathbf{p}$ \\
\hline \multirow{2}{*}{ Social } & Government & 90 & 20.84 & 5.068 & 0.534 & \multirow{2}{*}{0.495} & \multirow{2}{*}{198} & \multirow{2}{*}{0.621} \\
\hline & Private & 110 & 20.40 & 7.176 & 0.684 & & & \\
\hline \multirow{2}{*}{ Psychological } & Government & 90 & 6.38 & 1.673 & 0.176 & \multirow{2}{*}{0.796} & \multirow{2}{*}{198} & \multirow{2}{*}{0.427} \\
\hline & Private & 110 & 6.14 & 2.448 & 0.233 & & & \\
\hline \multirow{2}{*}{ Learning } & Government & 90 & 7.78 & 1.948 & 0.205 & \multirow{2}{*}{-1.611} & \multirow{2}{*}{198} & \multirow{2}{*}{0.109} \\
\hline & Private & 110 & 8.29 & 2.455 & 0.234 & & & \\
\hline \multirow{2}{*}{ Total } & Government & 90 & 35.00 & 7.591 & 0.800 & \multirow{2}{*}{0.128} & \multirow{2}{*}{198} & \multirow{2}{*}{0.898} \\
\hline & Private & 110 & 34.83 & 10.816 & 1.031 & & & \\
\hline
\end{tabular}

RQ3: Do teachers' beliefs concerning students' use of mobile devices vary on the basis of the teachers' Internet usage purpose?

In the testing of this research question, the t-test for independent samples and one-way ANOVA analysis were used. The analyses were applied separately to the sub-dimensions of the scale.

In the questionnaire applied to teachers, the participants were provided with six options concerning their purposes for using the Internet. These included: communicating with friends and relatives, reading e-mails and using social networking sites (Facebook, Twitter, etc...) Browsing web sites aligned with my interests, reading news, chatting, professional development, using the E-school system, watching shows/movies, personal development, using E-state applications, and shopping.

a. Communicating with friends

A statistically significant difference was determined between the teachers that use the Internet to communicate with their friends and those that do not use the Internet for that purpose, in terms of the scores they attained from the social and learning-related sub-dimensions and their total scores from the whole scale. The teachers that use the Internet to communicate have more positive beliefs in the social $(\mathrm{N}=138, \bar{X}=21.42)$, and learning $(\mathrm{N}=138, \bar{X}=8.32)$ dimensions of the scale and in the total scale points $(\mathrm{N}=138, \bar{X}=36.13)$, in comparison to those that do not use the Internet with that purpose. 
Table 11. The t-test results regarding Internet usage for communication

\begin{tabular}{|c|c|c|c|c|c|c|c|c|}
\hline & $\begin{array}{c}\text { Communicate } \\
\text { with friends }\end{array}$ & $\mathbf{N}$ & $\bar{X}$ & S. D. & S. E. & $\mathbf{t}$ & df & $\mathbf{p}$ \\
\hline \multirow{2}{*}{ Social } & No & 62 & 18.77 & 5.852 & 0.743 & \multirow{2}{*}{-2.792} & \multirow{2}{*}{198} & \multirow{2}{*}{$0.006^{*}$} \\
\hline & Yes & 138 & 21.42 & 6.347 & 0.540 & & & \\
\hline \multirow{2}{*}{ Psychological } & No & 62 & 5.92 & 1.927 & 0.245 & \multirow{2}{*}{-1.452} & \multirow{2}{*}{198} & \multirow{2}{*}{0.148} \\
\hline & Yes & 138 & 6.39 & 2.210 & 0.188 & & & \\
\hline \multirow{2}{*}{ Learning } & No & 62 & 7.48 & 1.940 & 0.246 & \multirow{2}{*}{-2.458} & \multirow{2}{*}{198} & \multirow{2}{*}{$0.015^{*}$} \\
\hline & Yes & 138 & 8.32 & 2.337 & 0.199 & & & \\
\hline \multirow{2}{*}{ Total } & No & 62 & 32.18 & 8.409 & 1.068 & \multirow{2}{*}{-2.773} & \multirow{2}{*}{198} & \multirow{2}{*}{$0.006^{*}$} \\
\hline & Yes & 138 & 36.13 & 9.704 & 0.826 & & & \\
\hline
\end{tabular}

b. Using social media sites (Facebook, Twitter, Instagram, etc...)

A statistically significant difference was also found in the mobile devices-related beliefs of the teachers that use the Internet to follow social media, and those that do not use the social media. This difference was significant in the learning dimension. Examining the average scores shows that the teachers using the social media $(\mathrm{N}=135, \bar{X} .=$ 8.36) have more positive beliefs than those that do not use social media in the learning dimension of the scale $(\mathrm{N}=135, \bar{X} .=7.43)$.

Table 12. The t-test results regarding Internet usage for social media

\begin{tabular}{|c|c|c|c|c|c|c|c|c|}
\hline & $\begin{array}{c}\text { Social } \\
\text { media sites }\end{array}$ & $\mathbf{N}$ & $\bar{X}$ & S. D. & S. E. & $\mathbf{t}$ & df & $\mathbf{p}$ \\
\hline \multirow{2}{*}{ Social } & No & 65 & 19.63 & 6.259 & 0.776 & \multirow{2}{*}{-1.514} & \multirow{2}{*}{198} & \multirow{2}{*}{0.132} \\
\hline & Yes & 135 & 21.07 & 6.295 & 0.542 & & & \\
\hline \multirow{2}{*}{ Psychological } & No & 65 & 6.09 & 2.199 & 0.273 & \multirow{2}{*}{-0.702} & \multirow{2}{*}{198} & \multirow{2}{*}{0.484} \\
\hline & Yes & 135 & 6.32 & 2.104 & 0.181 & & & \\
\hline \multirow{2}{*}{ Learning } & No & 65 & 7.43 & 2.046 & 0.254 & \multirow{2}{*}{-2.791} & \multirow{2}{*}{198} & \multirow{2}{*}{$0.006^{*}$} \\
\hline & Yes & 135 & 8.36 & 2.288 & 0.197 & & & \\
\hline \multirow{2}{*}{ Total } & No & 65 & 33.15 & 9.277 & 1.151 & \multirow{2}{*}{-1.823} & \multirow{2}{*}{198} & \multirow{2}{*}{0.070} \\
\hline & Yes & 135 & 35.75 & 9.494 & .817 & & & \\
\hline
\end{tabular}

c. Visiting web sites

It was determined that the teachers visiting websites related to their interests $(\mathrm{N}=157, \bar{X}=8,24)$ had more positive beliefs in relation with the learning dimension of the scale, in comparison to the teachers that did not use the Internet to visit web sites related to their interests.

Table 13. The t-test results regarding Internet usage for visiting web sites

\begin{tabular}{lcccccccc}
\hline & $\begin{array}{c}\text { Visiting } \\
\text { web sites }\end{array}$ & N & $\overline{\boldsymbol{X}}$ & S. D. & S. E. & t & df & \multirow{2}{*}{ P } \\
\hline \multirow{2}{*}{ Social } & No & 43 & 19.98 & 5.561 & 0.848 & \multirow{2}{*}{0.731} & \multirow{2}{*}{198} & \multirow{2}{*}{0.466} \\
\hline \multirow{2}{*}{ Psychological } & Yes & 157 & 20.77 & 6.498 & 0.519 & & \multirow{2}{*}{198} & \multirow{2}{*}{0.970} \\
\hline \multirow{2}{*}{ Learning } & No & 43 & 6.26 & 1.733 & 0.264 & \multirow{2}{*}{0.037} & & \multirow{2}{*}{198} \\
\hline \multirow{2}{*}{ Total } & Yes & 157 & 6.24 & 2.234 & 0.178 & $0.028^{*}$ \\
\hline
\end{tabular}

\section{d. Chatting}

According to the results of the analysis, the teachers that use the Internet for chatting attained significantly higher points than those that do not use the Internet to chat (learning $\mathrm{N}=70, \bar{X}=7.65$, total $\mathrm{N}=70, \bar{X}=33.88$ ) from the learning sub-dimension $(\mathrm{N}=70, \bar{X}=8.83)$ and the total scale itself $(\mathrm{N}=70, \bar{X}=36.80)$. 
Table 12. The t-test results regarding Internet usage for chat

\begin{tabular}{|c|c|c|c|c|c|c|c|c|}
\hline & Chatting & $\mathbf{N}$ & $\overline{\bar{X}}$ & S. D. & S. E. & $\mathbf{t}$ & df & $\mathbf{p}$ \\
\hline \multirow{2}{*}{ Social } & No & 130 & 20.18 & 5.484 & 0.481 & \multirow{2}{*}{-1.296} & \multirow{2}{*}{198} & \multirow{2}{*}{0.197} \\
\hline & Yes & 70 & 21.39 & 7.578 & 0.906 & & & \\
\hline \multirow{2}{*}{ Psychological } & No & 130 & 6.06 & 1.858 & 0.163 & \multirow{2}{*}{-1.665} & \multirow{2}{*}{198} & \multirow{2}{*}{0.097} \\
\hline & Yes & 70 & 6.59 & 2.545 & 0.304 & & & \\
\hline \multirow{2}{*}{ Learning } & No & 130 & 7.65 & 1.940 & 0.170 & \multirow{2}{*}{-3.653} & \multirow{2}{*}{198} & \multirow{2}{*}{$0.000^{*}$} \\
\hline & Yes & 70 & 8.83 & 2.576 & 0.308 & & & \\
\hline \multirow{2}{*}{ Total } & No & 130 & 33.88 & 8.004 & 0.702 & \multirow{2}{*}{-2.092} & \multirow{2}{*}{198} & \multirow{2}{*}{$0.038^{*}$} \\
\hline & Yes & 70 & 36.80 & 11.565 & 1.382 & & & \\
\hline
\end{tabular}

e. Personal development

The teachers using the Internet for personal development purposes $(\mathrm{N}=123)$ attained higher points than those that did not use the Internet for that purpose $(\mathrm{N}=77)$ in the learning dimension of the scale. According to this result, it is possible to assert that the teachers consulting the Internet for personal development have more positive beliefs concerning the use of mobile devices.

Table 12. The t-test results regarding Internet usage for personal development

\begin{tabular}{|c|c|c|c|c|c|c|c|c|}
\hline & $\begin{array}{c}\text { Personal } \\
\text { development }\end{array}$ & $\mathbf{N}$ & $\bar{X}$ & S. D. & S. E. & $\mathbf{t}$ & df & $\mathbf{p}$ \\
\hline \multirow{2}{*}{ Social } & No & 77 & 20.71 & 5.801 & 0.661 & \multirow{2}{*}{0.202} & \multirow{2}{*}{198} & \multirow{2}{*}{0.840} \\
\hline & Yes & 123 & 20.53 & 6.621 & 0.597 & & & \\
\hline \multirow{2}{*}{ Psychological } & No & 77 & 6.00 & 1.821 & 0.208 & \multirow{2}{*}{-1.288} & \multirow{2}{*}{198} & \multirow{2}{*}{0.199} \\
\hline & Yes & 123 & 6.40 & 2.300 & 0.207 & & & \\
\hline \multirow{2}{*}{ Learning } & No & 77 & 7.66 & 2.030 & 0.231 & \multirow{2}{*}{-1.992} & \multirow{2}{*}{198} & \multirow{2}{*}{$0.048 *$} \\
\hline & Yes & 123 & 8.31 & 2.351 & 0.212 & & & \\
\hline \multirow{2}{*}{ Total } & No & 77 & 34.38 & 8.373 & 0.954 & \multirow{2}{*}{-0.623} & \multirow{2}{*}{198} & \multirow{2}{*}{0.534} \\
\hline & Yes & 123 & 35.24 & 10.130 & 0.913 & & & \\
\hline
\end{tabular}

\section{f. Shopping}

Teachers that utilize the Internet for shopping $(\mathrm{N}=88)$ attained higher points from the learning dimension of the scale $(\bar{X}=8.58)$ than the teachers that did not state they used the Internet for shopping. According to this result, it is possible to state that the teachers that did not use the Internet for shopping have more negative beliefs concerning the effect of mobile device usage on learning $(\bar{X}=7.65)$.

Table 12. The t-test results regarding Internet usage for shopping

\begin{tabular}{|c|c|c|c|c|c|c|c|c|}
\hline & For shopping & $\mathbf{N}$ & $\overline{\boldsymbol{X}}$ & S. D. & S. E. & $\mathbf{t}$ & df & p \\
\hline \multirow{2}{*}{ Social } & No & 112 & 20.35 & 5.663 & 0.535 & \multirow{2}{*}{-0.636} & \multirow{2}{*}{198} & \multirow{2}{*}{0.525} \\
\hline & Yes & 88 & 20.92 & 7.057 & 0.752 & & & \\
\hline \multirow{2}{*}{ Psychological } & No & 112 & 6.17 & 1.903 & 0.180 & \multirow{2}{*}{-0.563} & \multirow{2}{*}{198} & \multirow{2}{*}{0.574} \\
\hline & Yes & 88 & 6.34 & 2.402 & 0.256 & & & \\
\hline \multirow{2}{*}{ Learning } & No & 112 & 7.65 & 2.048 & 0.193 & \multirow[b]{2}{*}{-2.950} & \multirow{2}{*}{198} & \multirow[b]{2}{*}{0.004} \\
\hline & Yes & 88 & 8.58 & 2.396 & 0.255 & & & \\
\hline \multirow{2}{*}{ Total } & No & 112 & 34.17 & 8.506 & 0.804 & \multirow{2}{*}{-1.239} & \multirow{2}{*}{198} & \multirow{2}{*}{0.217} \\
\hline & Yes & 88 & 35.84 & 10.565 & 1.126 & & & \\
\hline
\end{tabular}

Furthermore, the results indicate that while the teachers mostly use the Internet to visit web pages concerning their interests $(\mathrm{N}=157)$ and communicating with their friends and relatives $(\mathrm{N}=138)$, the teachers' least popular reasons to use the Internet are chatting $(\mathrm{N}=70)$ and shopping $(\mathrm{N}=88)$.

\section{DISCUSSION AND CONCLUSION}

The purpose of the present study is to examine teachers' beliefs concerning the effects of the use of mobile devices on students, and to determine whether these beliefs varied according to the demographic characteristics and 
Internet usage purposes. For this reason a demographic information questionnaire and the scale developed by Diker Coskun \& Kizilkaya Cumaoglu (2013) were revised and utilized. According to the results of the first problem of the study, teachers believe that students are affected by mobile devices on all three dimensions of the scale (social, psychological, and learning dimensions). This belief of teachers may affect the extent with which they integrate mobile devices to their teaching both in and out of the classroom. Indeed, the finding that teachers' beliefs directly affect ICT integration in teaching-learning processes is supported by several studies (Papanastasiou \& Angeli, 2008; Prestridge, 2012; Higgins, \& Moseley, 2001). From this perspective teacher beliefs concerning ICT use and its effects may be a reference to teachers' beliefs concerning mobile devices. Considering the possibility of using these devices in terms of mobile learning or to support technology in class, such beliefs of teachers may constitute an obstacle in utilizing them. Therefore, taking measures that would make teachers have more positive beliefs about mobile devices may be useful.

The study determined that the teachers' beliefs concerning mobile devices change significantly according to teachers' ages. Older teachers had more negative beliefs, particularly concerning the social effects of mobile devices. However, concerning mobile devices' psychological effects and effects on learning, no statistically significant difference could be found between teachers of different age groups. While some of the studies conducted on ICT integration reported age as a significant variable (Alazam, Bakar, Hamzah \& Asmiran, 2012), others (Mahdi $\&$ Al-Dera, 2013) reported that teachers' use of ICT does not differ according to their age. Considering the fact that teachers' beliefs, particularly in the learning dimension, would affect their use of this technology for learning purposes, the finding that the age variable does not change belief may be considered as a positive point. In addition, according to the results of the study, teachers' beliefs do not differ according to the type of organization (public or private) in which they work. While evaluating this finding, it should be taken into consideration that private school teachers utilize technology more frequently and more effectively in comparison with public school teachers. Similarly, teachers' beliefs did not differ in terms of gender. While the studies conducted on the use of technologies in the teaching environment generally seem to be in favor of male teachers (Jamieson-Proctor, Burnett, Finger \& Watson, G. (2006); Volman \& van Eck (2001)) the fact that no significant difference could be found in these beliefs is worth further examination.

Scientific studies concerning the variables with which teachers' mobile device-related beliefs interact and how these beliefs affect learning are not common. The present study, it was determined that the differences in teachers' purposes for using Internet are related to their beliefs concerning mobile devices. Within the scope of the study, six separate purposes for using the Internet were addressed (communication with friends, using social media sites, visiting web sites, chatting, personal development and shopping). The most striking finding of the study is related with the learning dimension of the beliefs concerning mobile devices scale. In every purpose for using the Internet that was examined within the study, it was determined that the teachers' beliefs concerning the "learning" dimension are always more positive than those that do not use the Internet for any given purpose. This may be explained through several different variables, but one of the most plausible explanation is that since connecting to the Internet through mobile devices is quite common nowadays, teachers' beliefs concerning these devices may become more positive as they continue to use them. Naturally, the fact that this difference manifests itself more clearly in the "learning" dimension may indicate that teachers are more concerned with the effects of mobile devices on learning, in comparison with the other dimensions. According to the results of the study, the only significant difference found in the social dimension was between the teachers that use the Internet to communicate with their friends and relatives, and those that do not use the Internet for this purpose. The unfolding of a difference under the "social" dimension in terms of the sole purpose of using the Internet for communication appears to be a matter that is worth further examination. Since the teachers that use the Internet for this purpose establish communication in the virtual environment themselves, they may have arrived at the conclusion that the virtual environment and therefore mobile devices would not negatively affect students. It was determined that the most positive beliefs concerning mobile devices were those of the teachers that use the Internet for chatting. However, examining this finding also requires attention to the fact that this was the least popular purpose for using the Internet among teachers. The pattern that emerges with this finding is of the quality of being the subject of educational researches concerning mobile devices. In conclusion, the findings of the current study determined that teachers' beliefs concerning mobile devices may be related to the purposes for which they use the Internet. 
Mobile devices' capacity to enable students to carry out both virtual and physical learning activities in the classroom and in an integrated environment reveals the potential of these devices to positively support learning. Accordingly, day by day mobile devices present a technology that can be used more effectively and efficiently than any other technology in the classroom. In consideration of the above mentioned potential of mobile devices, making efforts to integrate them with the classroom would be useful. One such effort would be to plan studies that would reveal the variables that would reveal the variables that would render the beliefs of teachers, one of the most important factors of the educational reform, concerning mobile devices positive. Future studies may also examine whether teachers own mobile devices and their usage patterns, and their relationship to with teachers' beliefs concerning mobile devices.

\section{AUTHOR INFORMATION}

Dr. Gonca Kızılkaya Cumaoğlu is an Assistant Prof. Dr. At Yeditepe University. She was graduated from Hacettepe Universitiy, Department of Computer \& Instructional Technologies. She also worked for 10 years as a Research Assistant while she was doing her PhD at the same department. In 2008 she studied on ERP (Enterprise Resource Planning) software at Germany. Among the courses given by her are as follows: Distance Education, Content and Learning Management Systems, Instructional Technologies, Materal Development and Practice Teaching. Her research fields includes digital literacy, digital footprints, mobile learning, and social networks

\section{REFERENCES}

Alazam, A. O., Bakar, A. R., Hamzah, R., \& Asmiran, S. (2013). Teachers' ICT skills and ICT integration in the classroom: The case of vocational and technical teachers in Malaysia. Creative Education, 3(08), 70.

Beranuy, M., Oberst, U., Carbonell, X., \& Chamarro, A. (2009). Problematic Internet and mobile phone use and clinical symptoms in college students: The role of emotional intelligence. Computers in Human Behavior, 25(5), 1182-1187.

Blackwel, C. K., Lauricella, A.R., Wartella, E., Robb, M., Schomburg, R. (2013). Adoption and use of technology in early education: The interplay of extrinsic barriers and teacher attitudes. Computers \& Education, 69, 310-319.

Bianchi, A., \& Phillips, J. G. (2005). Psychological predictors of problem mobile phone use. CyberPsychology \& Behavior, 8(1), 39-51.

Bollen, 1990, Overall fit in covariance structure models: Two types of sample size effects. Psychological Bulletin, 107, 256-259.

Brush, T., Glazewski, K. D., \& Hew, K. F. (2008). Development of an instrument to measure preservice teachers' technology skills, technology beliefs, and technology barriers. Computers in the Schools, 25(1-2), 112-125.

Cheon, J., Lee, S., Croocs, S. M., Song, J. (2012). An investigation of mobile learning readiness in higher education based on the theory of planned behavior. Computers \& Education, 59, 1054-1064.

Chen, L.. Y. (2008). Modeling the determinants of Internet use. Computers \& Education, 51, 545-558.

Chen, Y. F., Katz, J. E. (2009). Extending family to school life: College students' use of the mobile phone. Int. J. Human-Computer Studies 67, 179-191.

Ching, D., Shuler, C., Lewis, A., Levine, M. H. (2009) Harnessing the Potential of Mobile Technologies for Children and Learning. In A. Druin (Eds.), Mobile Technology for Children: Designing for Interaction and Learning. Morgan Kaufmann: USA.

Common Sense Media \& Joan Ganz Cooney Center. (2008). Growing up digital: adults rate the educational potential of new media and 21st-century skills. New York: Joan Ganz Cooney Center.

Coşkun, Y. D., \& Cumaoğlu, G. K. (2013). Scale of Teachers' Beliefs on the Effect of the Use of Mobile Devices on Students. Procedia-Social and Behavioral Sciences, 106, 2299-2306.

De-Marcos, L., Hilera, J. R., Barchino, R., Jiménez, L., Martínez, J. J., Gutiérrez, J. A., Gutiérrez, J. M., Otón, S. (2010). An experiment for improving students performance in secondary and tertiary education by means of m-learning auto-assessment. Computers \& Education, 55, 1069-1079

Drent, M., \& Meelissen, M. (2008). Which Factors Obstruct or Stimulate Teacher Educators to Use ICT Innovatively? Computers \& Education, 51(1), 187-199.

Druin, A. (2009) Introduction: Defining Mobile Technologies, Children and Learning. In A. Druin (Eds.), Mobile Technology for Children: Designing for Interaction and Learning. Morgan Kaufmann: USA. 
Field, R. (2005). Favourable conditions for effective and efficient learning in a blended face-to-face/online method. Proceedings of ASCILITE. Retrieved from http://www.ascilite.org.au/conferences/brisbane05/blogs/proceedings/23 Field.pdf

Gadermann, A. M., Guhn, M., \& Zumbo, B. D. (2012). Estimating ordinal reliability for Likert-type and ordinal item response data: A conceptual, empirical, and practical guide. Practical Assessment, Research \& Evaluation, 17(3), 1-13.

Hermans, R., Tondeur, J., van Braak, J., Valcke, M. (2008).The impact of primary school teachers' educational beliefs on the classroom use of computers. Computers \& Education, 51, 1499-1509.

Higgins, S., \& Moseley, D. (2001). Teachers' thinking about ICT and learning: beliefs and outcomes. Teacher Development, 5(2), 191-210.

Hoadley, C. (2009). Social Impacts of Mobile Technologies for Children: Keystone or Invasive Species? Mobile Technology for Children: Designing for Interaction and Learning. Morgan Kaufmann: USA.

Hwang, G., J., Wu, P-H., Ke , H-R. (2011). An interactive concept map approach to supporting mobile learning activities for natural science courses. Computers \& Education, 57, 2272-2280.

Jamieson-Proctor, R. M., Burnett, P. C., Finger, G., \& Watson, G. (2006). ICT integration and teachers' confidence in using ICT for teaching and learning in Queensland state schools. Australasian Journal of Educational Technology, 22(4).

Kamibeppu, K., \& Sugiura, H. (2005). Impact of the mobile phone on junior high-school students' friendships in the Tokyo metropolitan area.Cyberpsychology \& Behavior, 8(2), 121-130.

Liu, T.C., Wang, H.Y., Liang, J. K., Chan, T.W., Ko, H.W., Yang, J. C. (2003). Wireless and mobile technologies to enhance teaching and learning. Journal of Computer Assisted Learning, 19, 371-382.

Lumpe, A. T., \& Chambers, E. (2001). Assessing teachers' context beliefs about technology use. Journal of Research on Technology in Education, 34(1), 93-107.

Mahdi, H. S., \& Al-Dera, A. S. A. (2013). The Impact of Teachers' Age, Gender and Experience on the Use of Information and Communication Technology in EFL Teaching. English Language Teaching, 6(6), p57.

Nunnally, J. C. (1978). Psychometric theory (2nd ed.). New York, NY: McGraw-Hill.

Papanastasiou, E. C., \& Angeli, C. (2008). Evaluating the Use of ICT in Education: Psychometric Properties of the Survey of Factors Affecting Teachers Teaching with Technology (SFA-T3). Educational Technology \& Society, 11 (1), 69-86.

Plotnikoff, R. C. (1994). An application of protection motivation theory to coronary heart disease risk factor behaviour in three Australian samples: Community adults, cardiac patients, and school children. Unpublished doctoral dissertation, University of Newcastle, Newcastle, Australia.Porte, G. 1988. 'Poor language learners and their strategies for dealing with new vocabulary'. ELT Journal 42J3:167-72.

Prestridge, S. (2012). The beliefs behind the teacher that influences their ICT practices. Computers \& education, 58(1), 449-458.

Rossing, J. P., Miller, W. M., Cecil, A. K. \& Stamper, S. E. (2012), iLearning: The future of higher education? Student perceptions on learning with mobile tablets. Journal of the Scholarship of Teaching and Learning, 12(2), 1-26.

Sandberg, J., Maris, M., Geus, K. (2011). Mobile English learning: An evidence-based study with fifth graders. Computers \& Education, 57, 1334-1347.

Schermelleh-Engel, K., Moosbrugger, H., \& Müller, H. (2003). Evaluating the fit of structural equation models: Tests of significance and descriptive goodness-of-fit measures. Methods of psychological research online, $8(2), 23-74$.

Sung, E., Mayer, R. E. (2012). Students' beliefs about mobile devices Vs. desktop computers in South Korea and the United States. Computers \& Education, 59, 1328-1338.

Swan, K., Hooft, M., Kratcoski, A., Unger,D. (2005). Uses and Effects of Mobile Computing Devices in K-8 Classrooms. Journal of Research on Technology in Education, (38)1.

Şad, N., Akdağ, M. (2010). İngilizce dersinde cep telefonlarılla üretilen sözlü performans ödevlerinin yazılı performans ödevleriyle karşılaştırılması. Türk Eğitim Bilimleri Dergisi, 8(3), 719-740.

Takao, M., Takahashi, S., \& Kitamura, M. (2009). Addictive personality and problematic mobile phone use. CyberPsychology \& Behavior, 12(5), 501-507.

Thomée, S., Dellve, L., Härenstam, A., \& Hagberg, M. (2010). Perceived connections between information and communication technology use and mental symptoms among young adults-a qualitative study. BMC Public Health,10(1), 66 . 
Uzunboylu, H. Özdamlı,, F. (2011). Teacher perception for m-learning: scale development and teachers’ perceptions. Journal of Computer Assisted Learning, 27, 544-556.

Volman, M., \& van Eck, E. (2001). Gender equity and information technology in education: The second decade. Review of Educational Research, 71(4), 613-634.

Yang, S. H. (2012). Exploring College Students' Attitudes and Self-Efficacy of Mobile Learning. Turkish Online Journal of Educational Technology-TOJET,11(4), 148-154.

Yen, C. F., Tang, T. C., Yen, J. Y., Lin, H. C., Huang, C. F., Liu, S. C., \& Ko, C. H. (2009). Symptoms of problematic cellular phone use, functional impairment and its association with depression among adolescents in Southern Taiwan. Journal of Adolescence, 32(4), 863-873. 